\title{
PERSPECTIVES OF VOLUNTEER PRE-SERVICE TEACHERS AND PARENTS ON A SUMMER PROGRAM FOR CHILDREN WITH AUTISM SPECTRUM DISORDERS ${ }^{i}$
}

\author{
Hatice Şengül Erdem ${ }^{\text {ii }}$ \\ PhD, İstanbul Medipol University, \\ Faculty of Education, \\ Turkey
}

\begin{abstract}
:
Children with autism spectrum disorders (ASD) are more likely to have regression in acquired skills in summer than typically developing peers, while parents have also more limited options to provide summer alternatives for their children. This study aimed to understand perspectives of parents of children with ASD and pre-service teachers volunteered on a social enhancement summer program delivered through a university for children with ASD. Semi-structured interviews were performed with both participant groups along with focus group discussion with volunteers, while an inductive analysis process was used for data analysis. The analysis of data obtained from both parents and volunteers revealed three main themes along with related subthemes: (a) the need for summer program, (b) suggestions for effective summer program, and (c) benefits of the summer program. The perspectives of two groups of participants generally overlap and they demonstrate similar thoughts. The results show that summer programs can be an effective alternative to maintain the current level of children with ASD in summers.
\end{abstract}

Keywords: summer program, autism spectrum disorders, perspectives, volunteering, social skill

\section{Introduction}

Participating in social activities with other people has positive effects on social and personal development (Law \& King, 2000), while individuals with disabilities, especially children with autism spectrum disorders (ASD) are particularly disadvantageous in

\footnotetext{
${ }^{i}$ A part of the study was presented with the title "Perspectives of volunteer pre-service teachers on a summer program for children with autism spectrum disorders" in $6^{\text {th }}$ International Conference On Lifelong Education And Leadership For All-ICLEL 2020.

ii Correspondence: email herdem@medipol.edu.tr
} 
terms of accessing community environments and participating in social activities than their peers (Hilton et al., 2008; Solish et al., 2010).

The summer months among students with special needs are particularly important given that they regress more than students in the general population during summer break (Duncan, 2016), by staying at home with feelings of isolation and boredom during the entire summer (Leslie, 2018; Siperstein et al., 2011). The regression involves academic achievement (Cooper et al., 1996) and adaptive and social skills such as home living skills (Menousek, 1983, Duncan, 2016). Parents of children with developmental disabilities also consider the summer to be overwhelming and stressful due to its unstructured nature (Duncan, 2016; Randel et al., 2015). Accordingly, the social needs of children with ASD are a specific area of focus that should particularly be addressed within the context of long break in schooling during the summer months (Cross, 2013).

Summer programs and camps are considered to provide an important opportunity for children with ASD in this regard (Brookman et al., 2003; Walker et al., 2010), given their association with enhanced social skills (Brookman et al., 2003; Lopata et al., 2006; Lopata et al., 2008; Maich et al., 2015; Rynders et al., 1990; Walker et al., 2010), significant decrease in social anxiety (Kaboski et al., 2014) and problem behaviours (Duncan, 2016; Lopata et al., 2008) and diminished regression of skills (Cross, 2013; Bobzien \& Judge, 2014) as reported in many studies among children with ASD. During the summer program, children with ASD have a unique opportunity to enhance and expand their skills in a natural social setting (Leslie, 2018), while at the same time enjoy the leisure (Boeder, 2012), have fun and adventure and the opportunity to interact with peers or volunteers (Bobzien \& Judge, 2014).

Although approaches, strategies or structures of the summer programs for children with ASD differ considerably and the duration may range from four weeks to twenty weeks (Brookman et al., 2003, Walker et al., 2010, Solomon et al., 2004), the overall aim remains to be the maintenance of current functioning level, motivation for acquisition of new skills (Brookman et al., 2003, Walker et al., 2010, Solomon et al., 2004) and enhanced social behaviours (Lopata et al., 2006; Lopata et. al, 2008; Solomon et al., 2004). In this regard, current practice involves a half-day program and recreational activities (e.g., dance and, swimming) based on intervention program including priming and self-management by fading prompts (Brookman et al., 2003), sensory-motor and language-based play (Walker et al., 2010), therapeutic cooperative activities (Lopata et al., 2008), instruction, practice, and reinforcement (Solomon et al., 2004), and cooperative learning strategies and positive reinforcement (Rynders et al., 1990).

Summer also involves financial issues for parents because while they work, they must care for and create opportunity for leisure and recreational activities for their children that require financial resources (Duncan, 2016; King et al., 2003). However, while inclusive summer programs heavily focus on supporting social skills of children with ASD via peer or adult, most of them could not reach trained volunteers who are able to participate regularly (Boyd et al., 2008; Brookman et al., 2003). Hence, universities are considered to be ideal candidates with potential of conducting efficient volunteering 
programs, due to their research culture alongside the ability to provide volunteers with high instinct motivation, and to develop integrated programs of training, research, and social action (Nieto et al., 2015). Indeed, a research was conducted by a public university in Spain that aimed to support people with ASD in leisure time via volunteer university students (Nieto et al., 2015). The structured program lasted one year, and each volunteer was assigned with an individual with ASD and spent time together for four hours per week during leisure. The findings revealed high level of satisfaction from families and volunteers and showed that volunteering programs to support people with ASD can be successfully implemented in universities (Nieto et al., 2015).

The purpose of the present study was to evaluate the utility of a one-month, halfday summer program conducted by a university as a volunteering program for children with ASD, and to evaluate the efficacy of the program through opinions, experiences and suggestions of parents of children with ASD and volunteers who have participated in the program. The findings will provide evidence for the need of summer program for children with ASD, strategies to maximize the effectiveness of programs, and benefits for volunteers, parents and children with ASD.

\section{Method}

This qualitative research has been conducted using a phenomenology design that investigates the meanings of people derived from their lived experiences (Brantlinger et al., 2005). In keeping with this perspective, this design was used to explore the experiences, perspectives and suggestions of parents of children with ASD who participated a social enhancament program and their volunteers.

\subsection{Participants}

The study was carried out with a group of 19 participants, consisting of 9 parents (8 mothers and 1 grandmother, aged 38 to 62 years) of children with ASD and volunteers of undergraduate students ( 8 female and 2 male students with a mean age of 26.7 years) participated in the program. Homogeneous sampling strategy was determined as a purposeful sampling because it was aimed to identify summer program effect on a group who have a similar characteristic (Creswell, 2014; Patton, 1990).

Table 1: Descriptive data for participants

\begin{tabular}{|c|c|c|c|c|c|}
\hline Participant & Age & Education & $\begin{array}{c}\text { Marital } \\
\text { status }\end{array}$ & $\begin{array}{l}\text { Details of child } \\
\text { with ASD }\end{array}$ & $\begin{array}{c}\text { Employment } \\
\text { status }\end{array}$ \\
\hline $\begin{array}{l}\text { Parent } 1 \\
\text { (Mother) }\end{array}$ & 46 & High school & Divorced & $\begin{array}{l}\text { 10-year-old (yo) daughter } \\
\text { attending } 4^{\text {th }} \text { grade special } \\
\text { education class (SEC) }\end{array}$ & Self-employed \\
\hline $\begin{array}{l}\text { Parent } 2 \\
\text { (Grandmother) }\end{array}$ & 62 & Collage & Married & $\begin{array}{l}8 \text { yo grandson who is included } \\
\text { in } 3^{\text {rd }} \text { grade }\end{array}$ & Retired \\
\hline $\begin{array}{l}\text { Parent } 3 \\
\text { (Mother) }\end{array}$ & 50 & $\begin{array}{c}\text { Master's } \\
\text { degree }\end{array}$ & Divorced & $\begin{array}{l}14 \text { yo son attending } 9^{\text {th }} \text { grade } \\
\text { special education school (SES) }\end{array}$ & $\begin{array}{c}\text { Business } \\
\text { coach }\end{array}$ \\
\hline Parent 4 & 38 & High school & Married & 8 yo son who is included & Housewife \\
\hline
\end{tabular}


Hatice Şengül Erdem

PERSPECTIVES OF VOLUNTEER PRE-SERVICE TEACHERS AND PARENTS

ON A SUMMER PROGRAM FOR CHILDREN WITH AUTISM SPECTRUM DISORDERS

\begin{tabular}{|c|c|c|c|c|c|}
\hline (Mother) & & & & in $3^{\text {rd }}$ grade & \\
\hline $\begin{array}{l}\text { Parent } 5 \\
\text { (Mother) }\end{array}$ & 55 & $\begin{array}{l}\text { Secondary } \\
\text { school }\end{array}$ & Married & $\begin{array}{l}14 \text { yo son who is included } \\
\text { in } 8^{\text {th }} \text { grade }\end{array}$ & Housewife \\
\hline $\begin{array}{l}\text { Parent } 6 \\
\text { (Mother) }\end{array}$ & 50 & $\begin{array}{l}\text { Master's } \\
\text { degree }\end{array}$ & Married & $\begin{array}{l}11 \text { yo son is included } \\
\text { in } 4^{\text {th }} \text { grade }\end{array}$ & Pharmacist \\
\hline $\begin{array}{l}\text { Parent } 7 \\
\text { (Mother) }\end{array}$ & 45 & Collage & Divorced & $\begin{array}{c}14 \text { yo daughter attending } \\
7^{\text {th }} \text { grade SEC }\end{array}$ & Housewife \\
\hline $\begin{array}{l}\text { Parent } 8 \\
\text { (Mother) }\end{array}$ & 45 & Collage & Divorced & $\begin{array}{l}12 \text { yo daughter who is } \\
\text { included in } 7^{\text {th }} \text { grade }\end{array}$ & Teacher \\
\hline $\begin{array}{l}\text { Parent } 9 \\
\text { (Mother) }\end{array}$ & 40 & $\begin{array}{c}\text { Master's } \\
\text { degree }\end{array}$ & Divorced & $\begin{array}{l}12 \text { yo son attending } \\
4^{\text {th }} \text { grade } S E C\end{array}$ & Engineer \\
\hline Volunteer 1 & 22 & Senior & Single & $\begin{array}{c}\text { Paired with a grandson } \\
\text { of parent } 2\end{array}$ & Student \\
\hline Volunteer 2 & 29 & Senior & Single & $\begin{array}{c}\text { Paired with a grandson } \\
\text { of parent } 9\end{array}$ & Student \\
\hline Volunteer 3 & 31 & Senior & Single & $\begin{array}{c}\text { Paired with a child } \\
\text { of parent } 3\end{array}$ & $\begin{array}{c}\text { Student/ } \\
\text { Works in SES }\end{array}$ \\
\hline Volunteer 4 & 21 & Senior & Single & $\begin{array}{c}\text { Paired with a child } \\
\text { of parent } 8\end{array}$ & Student \\
\hline Volunteer 5 & 21 & Senior & Single & $\begin{array}{l}\text { Paired with a child } \\
\text { of parent } 7\end{array}$ & Student \\
\hline Volunteer 6 & 29 & Collage & Single & $\begin{array}{c}\text { Paired with a child } \\
\text { of parent } 4\end{array}$ & Works in SES \\
\hline Volunteer 7 & 27 & Senior & Single & $\begin{array}{c}\text { Paired with a child } \\
\text { of parent } 5\end{array}$ & Student \\
\hline Volunteer 8 & 27 & Senior & Single & $\begin{array}{c}\text { Paired with a child } \\
\text { of parent } 1\end{array}$ & Student \\
\hline Volunteer 9 & 30 & Senior & Single & $\begin{array}{l}\text { Paired with a child } \\
\text { of parent } 6\end{array}$ & Student \\
\hline Volunteer 10 & 30 & Senior & Single & $\begin{array}{l}\text { Paired with a } 12 \text { yo } \\
\text { boy (his parent does not } \\
\text { participate the study) }\end{array}$ & Student \\
\hline
\end{tabular}

\subsection{Description of summer program}

The program was conducted through collaboration among stakeholders including the Ministry of National Education, an Autism Association supporting families of children with ASD, and a private university in Istanbul. The university recruited the volunteer pre-service teachers from special education department while the community undertook to find participants with ASD. Each volunteer was paired up 1:1 with a child with ASD. The pairing process was completed before the program, and the volunteers made home visits to get information about the participating students' current performance level and Individualized Education Program (IEP) goals to modify the content of the program according to the needs of the students and their parents.

The goals of this summer program were three-fold: (1) to provide the maintenance of acquired skills of children with ASD in a social environment promoting their social skills in an inclusive setting during summer term, (2) to enable professional development 
of pre-service special education teachers, (3) to support families by creating an alternative for summer.

\subsubsection{Setting}

The program was conducted from 12:30 p.m. to 04:30 p.m. every weekday at a special education school during July 2019. Professionals from a range of disciplines who had an experience of working with children with special needs provided support to the program. The program was conducted at a special education school affiliated with the Ministry of National Education.

\subsubsection{Program}

The program mainly aimed to enhance the social and adjustment skills of students with ASD by providing group activities. Two group formats were commonly used to achieve this aim: a sub-group that composed of a volunteer and child with ASD and a large group that consisted of all participants including the coordinator. The involvement in formal activities which refer to structured activities that include rules or objectives and have an officially identified leader or instructor (King et al., 2003) was actualized throughout the program. IEP sessions, which were developed after the visit to families, were also a part of the program.

The time from 12:30 to 16:30 p.m. was divided into five or six sessions, each lasting between 30-40 minutes. A typically scheduled day started with an outdoor activity such as a ball game (about 30 minutes with large group), followed by a cooking workshop including preparing snacks and eating them (about 40 minutes with large group). After the break, an IEP session was conducted on two days of the week. On the other days of the week, art activities such as painting and ceramic were programmed as followed by an activity in the gym or the park. The activities with sub-group and large group were planned as therapeutic activities aimed to develop social skills while IEP sessions were primarily academic-oriented. During the implementation of the program, the integrity of the program was primarily considered, which means the curriculum was followed as written to improve the success of summer program (Quinn et al., 2014). The curriculum was prepared weekly and was sent to all volunteers and families at the beginning of each week. This was the way to provide integrity.

\subsubsection{Participants of program}

\section{A. Participants with ASD}

A total of 10 students with ASD, who were between the ages of 7-14, were enrolled in the program. Four of 10 students had siblings while 6 of them were the only child in the family. All students were identified to be attending either public or private schools to receive special education services, while 6 of them were also involved in sports programs. In addition, 4 of the students were in special education classes, 4 of them were in inclusive education and 2 of them were students at special education schools. Four out of 10 
students were also receiving speech and language therapy services for two hours per week.

\section{B. Volunteer pre-service teachers}

The recruitment criteria for volunteers were to have successfully completed prerequisite courses such as Applied Behaviour Analysis, Individualized Education Plan, and Teaching Social Skills to Children with ASD. Candidates were pre-interviewed by the coordinator and were informed about the schedule and program requirements such as showing compulsory attendance, getting prepared for daily programs, taking main responsibility of paired participants with ASD, working collaboratively with the parents and the coordinator and then the candidates who agreed to take all the responsibilities were identified as volunteers.

\section{Coordinator}

The author of the study coordinated the program. She developed the weekly plan and required materials to conduct the activities, and supported volunteers at the end of each week. She also attended the program every day to check the scheduled day and interfered in any crises that may arise concerning children or volunteers.

\subsection{Data Collection}

Data was obtained by semi-structured interviews with participants. Open-ended questions developed by coordinator were reviewed by two academicians who are expert in qualitative research methods. Two question sets involving 12 and 11 open-ended questions were used in parent and volunteer groups, respectively that elicit their experiences and thoughts related to the program. Interviews, ranging from 20 to 30 minutes, were completed on a one-to-one basis. They were assured that their individual responses would be treated as confidential. Focus group lasted 110 minutes. All the focus group and interviews were conducted by the author in last week of program.

\subsection{Data Analysis}

All interviews were digitally recorded and transcribed verbatim. Data from each group was analysed separately using an inductive thematic approach (Yıldırım \& Şimşek, 2005) by the line by line examination (Strauss \& Corbin, 1998). Transcriptions were read out by the author and two research assistants for the first coding. During the open coding phase, each coder independently read the same three interview transcripts from two different participant groups and identified units of meaning related to the aims of the research. Coders came together to group similar units as emerging categories. After all transcripts were individually analysed, the interconnectedness between categories organized into subthemes and then themes. During this process, it was realized that the codes overlapped between two participant groups and analysis was conducted by combining the two groups. 


\subsubsection{Reliability}

To increase reliability for coding accuracy three interviews from each participant group (approximately \%30) were randomly selected and coded separately by the researcher and a research assistant. Intercoder reliability score was found 85\%. Discrepancies between coders were discussed and consensus was reached. Throughout the analysis process, consultation from a senior qualitative researcher was requested on subthemes/themes formulation, coding and evaluation of the outcomes. Additionally, data triangulation was provided for a multidimensional perspective of the data (Golafshani, 2003). Triangulation consisted the transcripts of the interviews, focus group discussion with volunteers, and researcher field notes.

\section{Results}

Analysis of data obtained from both parents and volunteers revealed the three main themes with related subthemes: (a) the need for summer program, (b) suggestions for effective summer program, and (c) contributions of summer program. The perspectives of two groups of participants generally overlap and they demonstrate similar thoughts regarding themes and subthemes.

\subsection{The need for summer program}

Participants considered a summer term program to be necessary based on two subthemes including (a) for professional development of pre-service special education teachers and (b) for an urgent need of program or school during summer for children with ASD and their families.

\subsubsection{The prerequisite for volunteer pre-service teachers' professional experience}

Eight volunteers stated that they consider this program as an opportunity to practice and to improve their professional skills before graduation. Three parents also stated that such programs are an important opportunity for pre-service teachers to have professional experience before graduation. Excerpts from participants' interviews to explain this point are as follows,

“...professionals from different disciplines make their own planned activities or workshops...we are meeting many professionals who are experienced working children with ASD, we observe them and gain a lot of experience... we will be able to use in professional life what we have learned here. Honestly, we did not get experience during internship as much as here..." (Volunteer 7)

"I think that this type of program is very useful for volunteers for their development. Of course, they are getting a good academic education, but here while they spend time with their assigned child, they observe other children too. In my sense, it is an opportunity to see a spectrum of different children." (Parent 3) 
The desire of volunteers to understand ASD has also emerged as a source of professional development. Three volunteers claimed that they participated in the program to gain a better insight into ASD and have a chance to be together with a child with ASD during a month. One volunteer said,

".... I have decided to participate to get know ASD well. Also, I am really interested in ASD but have never worked a child with ASD. I thought it was the best way for my summer break..." (Volunteer 1)

Two volunteers stated that their main motivation was to participate in a program with no specific expectations. One volunteer described her motivation as follows:

".... if I had such a chance again, I would come because we have no worries here, no worries about payment, no worries about accountability. This is totally voluntary because this is what makes me feel very good, anything from those kids, such as a hug or anything they have accomplished, a product they have made, and I feel more satisfied and happier. So, I would like to join again...." (Volunteer 3)

\subsubsection{The need for a summer program for children with ASD and their families}

Most of parents and volunteers consistently expressed the need for a program in the summer. A total of five parents and two volunteers reported feeling helpless since the long summer period makes summer programs necessary. A grandparent explained this need as,

"Honestly, I didn't know what we would do during the summer... my grandson would be with me because his mom and dad must work. He has a shadow teacher that has just started. So, it was much better to be here than stay at home because what we can do with him is very limited ... He doesn't like any activity, he gets bored very quickly everywhere ... The program here with special education teachers turned out to be very efficient." (Parent 2)

Participants also mentioned limited summer programs or schools for children with ASD (3 parents and 2 volunteers), limited financial resources and limited time due to the parents' work (4 parents and 1 volunteer) as the reasons for the need for the summer program. A mother expressed her concern, saying,

"We usually have very serious difficulties in summer months. My son has much leisure time, but I cannot create opportunities for him because the price for summer schools exceeds our budget by far. Really, they are not affordable. There are already several things we have planned for him. On the other hand, this idleness means he deteriorates..." (Parent 9) 
The last reason pointed out by three parents and one volunteer is the lack of activities and leisure time opportunities in summer for children with ASD. A volunteer stated this limitation, saying,

"If we evaluate it in terms of children... first, children are spending all summer at home if families work. They can't spend enough time for their kids. When children attend programs like this, the children have fun with the activities. Because children are not isolated at home, families do not have difficulties to keep their daily routine. Because children have a good time during the day, families do not spend more energy to maintain their daily life." (Volunteer 10)

A mother stated that her daughter was not admitted to the summer school, which was run free by local administration because of her ASD diagnosis. The following is the statement of the mother:

"Last summer, I saw an advertisement in my town. They posted ads so that you can enrol your children in free summer schools. So I went to the municipality and asked, "Can I register my daughter with ASD?" They said, "We do not accept children with disabilities." There is really no opportunity for us that we can take advantage of" (Parent 7)

\subsection{Suggestions for effective summer program}

Participants described recommendations based on experiences gained through the program. These recommendations emerged as five subthemes: structure of the program, involvement of typically developing peers, partnership accessibility and family empowerment.

\subsubsection{Structure of the program}

The participants thought that some changes in the structure are required for more effective program. The most frequently cited recommendations referred to more diversity by including more sports (i.e. swimming), arts and outdoor (i.e. trips) activities such as swimming, more outdoor activities such as trips. Adding professionals who are experienced in working individuals with ASD in arts and sports to the program was also recommended.

Another suggestion reported by volunteers more than parents about the structure is grouping of participants with ASD. A total of four volunteers and two parents recommended that children with ASD should be subdivided into ASD characteristics. Severity of ASD is seen as a major factor for program to determine the content and structure. Children with similar ASD characteristics should be grouped and the program should be differentiated. A similar suggestion that was stated by three volunteers and two parents was to group children by age.

One factor to reveal the need to differentiate children according to their ASD characteristics is the concern caused by problem behaviours showed by children who did 
not have them before because they imitated other children with these problem behaviours. One mother described her concern follows:

"As you know, these children imitate everything either positive or negative. We detected a couple of negative behaviours that my daughter had never done before. We felt a little bit concerned because it is very hard to change any behaviour." (Parent 7)

The participants were concerned about the physical environment and made some suggestions for more enriched environment. The most striking suggestion was to provide a wider, more natural area that does not look like a school. Five parents and four volunteers stated that the program should enable children to harmonize with nature.

Another suggestion under the structure of the program is communication between families and volunteers. Parents expect more frequent communication either before or during the program. Three parents and one volunteer recommended ways to achieve this by such means as sending daily notes to home summarizing developments and problems encountered on a daily basis, making some suggestions for home, visiting homes at least once before the program starts, discussing the child's individualized program at the beginning with parents and developing it based on observation on child's natural environment. As one volunteer (Volunteer 8) described, "I might want to know what the parents think about me or what they expect from us. I might want to know what they're saying about their kids."

\subsubsection{Involvement of typically developing peers}

This subtheme emerged as participants described socialization need of children with ASD with peers. Despite the participation of typically developing peers was planned, it was not achieved due to the restriction in accessibility. Three parents and four volunteers reported that not only children with ASD but also typically developing children may benefit more from the program if typical ones are included. Parents who have a child attending special education classes see the program as an essential opportunity for their children to become friends and interact with their typical peers because their education environment is not inclusive.

\subsubsection{Collaboration between partnerships}

It was suggested that collaboration between relevant institutions was required to carry out the program more effectively, reach more families and volunteers and extend it longer than a month. Almost all parents and more than half of volunteers consider that Ministry of National Education should be the leading institution to provide this requirement and include universities, non-governmental organizations, associations, and local authorities. Participants also thought that contribution of autism societies is limited, and the government or public institutions should directly manage the program. One mother (Mother 6), emphasized the role of universities in the collaboration and said, "The host of these programs is universities. They meet all criteria such as financial resources, academics, 
volunteer students, and physical facilities." Another mother (Parent 1) expressed her trust on universities, saying, "You look like a seed and I really appreciate what you are trying to do. I believe you will achieve something that people think that it will never come true. I do not like this point of view."

\subsubsection{Program accessibility}

Another emerging subtheme is increasing the program's accessibility to reach more families and plan more programs for the children with ASD and create opportunity for volunteers to gain professional experience. To achieve this, the program should be announced through different channels and the above-mentioned cooperation must be provided. Seven parents and six volunteers considered social media as the most powerful channel for publicity. Additionally, evaluation and sharing of program outcomes are considered important to make the program more accessible. One mother (Parent 1) stated, "All partners should participate in the dissemination of the program. In the summer, these children do not become normal or disappear."

\subsubsection{Family empowerment}

The subtheme of family empowerment was mentioned by eight parents and two volunteers. Parents expressed challenges while raising their children with ASD in the interviews. This need emerged because of challenges. Participation of families in the activities and organization of seminars or workshop based on family's needs are two of the most common suggestions. Parents indicated that a workshop about effective ways to deal with problem behaviours conducted with an academic was efficient and contributed to their skills as parents. One of them (Parent 6) said, "I learned that negotiation may be an effective way to communicate with my daughter. Ignoring is not always useful and I have started to negotiate after the workshop. I saw it worked."

Table 2 shows the list of suggestions and example quotations from both participant groups.

Table 2: Suggestions for increasing the effectiveness of programs

\section{Sample statement}

Improved structure of the program
"Well, it may be held in a greener setting... there could have been more outdoor activities and sports. This summer program looks more academic oriented. Also, children's performance level was different from each other." (Parent 9)

"I imagine an environment with lots of trees... our children are busy with soil in a garden. They are planting seeds and then watering them... then they collect fruits or vegetables..., I wish they were in such an environment." (Parent 7)

"There should be definitely more sports... This year we used the school's field, garden and gym very well, but may be a sports coach and someone who has experience working with children with autism would have been more efficient if they supported us." (Volunteer 1)

"It was good to add an individualized quality to the program. But I thought that it would be more efficient if it was given at the beginning rather than on the last day of program. Volunteers visited us before the start and asked many questions in detail to prepare my kid's program. It was good but I did not know anything about this before 


\begin{tabular}{|c|c|}
\hline & $\begin{array}{l}\text { the program. I wish I had been informed about the program on a daily basis." (Parent } \\
\text { 3) }\end{array}$ \\
\hline $\begin{array}{l}\text { Involvement of } \\
\text { typically } \\
\text { developing peers }\end{array}$ & $\begin{array}{l}\text { "In the meantime, some typically developing children visited the school and my son } \\
\text { played soccer; he played very well with them. If they came together often, I believe other } \\
\text { children could get to know our children better too." (Parent 4) } \\
\text { "Typically developing children can also be included for a more effective program. If } 10 \\
\text { children with ASD participate, } 10 \text { typical children may also participate too. Children } \\
\text { with ASD can learn a lot from their peers. During the lessons we learned that peer } \\
\text { learning is a strong way to learn for children with special needs." (Volunteer 2) }\end{array}$ \\
\hline $\begin{array}{l}\text { Collaboration } \\
\text { between } \\
\text { partnerships/partners }\end{array}$ & $\begin{array}{l}\text { "As I said, strong cooperation is required. Summers are very long and there is a lot of } \\
\text { free time left... so families need to fill this time but do not know how to do that. } \\
\text { Additionally, financial resources are restricted. All these make his cooperation } \\
\text { necessary. So, I think it would be beneficial for everyone to expand this type of program } \\
\text { with the cooperation of the state, universities, the Ministry of National Education, and } \\
\text { NGOs. This is necessary for not only families but also professionals and society." } \\
\text { (Parent 3) } \\
\text { "Our Ministry of National Education should be the leading institution to organize } \\
\text { things... and to work to reach even more families. With their official announcements, } \\
\text { more resources can be accessible, and more experts may be interested in supporting } \\
\text { this program..." (Volunteer 10) }\end{array}$ \\
\hline oility & $\begin{array}{l}\text { "I hope more sponsors can be found and summer program becomes more common. We } \\
\text { really need to rest in summer even for a month." (Parent 5) } \\
\text { "We announced this program through an association and reached participants. But } \\
\text { this is a very local one. To increase programs the support of the National Education is } \\
\text { required. We have already used their school. Many programs can be carried out at the } \\
\text { same time in many schools, more children can be reached... volunteers not only from } \\
\text { our university but also from other universities can participate and gain experience... I } \\
\text { believe that our national education and universities can achieve this together..." } \\
\text { (Volunteer } 1 \text { ) }\end{array}$ \\
\hline $\begin{array}{l}\text { Family } \\
\text { empowerment }\end{array}$ & $\begin{array}{l}\text { "It would be very nice if the number of seminars or workshops was increased because } \\
\text { we need to be educated on some issues. For example, my biggest fear is puberty of my } \\
\text { daughter and it is approaching. But I do not know what to do about it and I really need } \\
\text { suggestions about how to deal with such problems and behavioural problems caused } \\
\text { by puberty." (Parent } 7 \text { ). } \\
\text { "Family involvement can be achieved by engaging families in daily activities or } \\
\text { requesting them to arrange things and participate in the activities. I don't know if all } \\
\text { families can manage it but this can be organized once a week." (Volunteer 9) }\end{array}$ \\
\hline
\end{tabular}

\subsection{Benefits of summer program}

The third main theme that emerged from the analysis of interview transcripts was the impact of the program on parents, volunteers, and children with ASD.

\subsubsection{Professional development}

Participants stated that the program contributed to the professional skill of volunteer preservice teachers, while both volunteers and parents thought that special education requires field experience and this program created an area for it. One parent (Parent 3) describes how the program develops volunteers' skills as follows: 
"Of course, they are getting a good academic education. Besides, the program is very beneficial for their development because while each one spends time with one child, they observe other children and see their different features. In my opinion, this is a contribution to this field, too, because it brings more experienced experts to the field."

Six of the volunteers also noted that they felt more motivated before they begin professional life thanks to their increased knowledge in ASD. One volunteer (Volunteer 1) expressed his/her views on motivation, saying,

"Our energy was high, it increased our motivation, and it was also passed on to children. In this process, we had the chance to put theory into practice. It was the greatest contribution."

Another volunteer (Volunteer 6) remarked,

"I have learnt a lot from working with children diagnosed with ASD and observing them performing different things, different problem behaviours and different stereotypical patterns. I was able to experience all of them simultaneously."

All volunteers stated that they would like to participate in similar programs even after they graduate. One volunteer (Volunteer 8) talked about participating again, saying,

"I would really like it, it was definitely a very useful program for me, I think not only for me, but for everyone. For families and for kids as well."

\subsubsection{Skills of children with ASD}

Two participant groups stated that there was improvement in the skills of participant children, particularly in their social skills. Social development showed itself in different areas. One area pointed by five parents and five volunteers is more participation to group activities such as acting with the group in harmony and staying longer within activities. This contribution is clear in a parent's statement (Parent 3):

"He started to be better adjusted... especially in the last week, he participated in more events than before, his attempts to escape from activities or group decreased.... The greatest benefit was that he could spend more time with his peers."

Similarly, a volunteer (Volunteer 4) said, "at the beginning, she did not want to participate in group activities... she did not want to remain in desk activities... She overcame this at the end of the first week."

Two mothers stated that their children continue to show this improvement at home. One (Parent 8) described this change as follows: 
"When she started doing activities here, she also started doing them at home. She wants to continue or complete at home instead of watching television or film screenings. I observe that she is doing more fun and educative activities at home."

Improvement in academic skills was stated by both participant groups. One mother (Parent 5) said,

"They studied literacy in IEP sessions, and the volunteer informed me session by session. We, as parents, would not be able to teach him in summer. ... We do not have such energy, neither I nor my husband."

A close relationship between participating children and volunteers has been seen as a facilitator contributing to children's development. One volunteer (Volunteer 9) said, for example,

"I think I have had a close relation with him. Otherwise, it could be very difficult to achieve improvement. This closeness is mutual, that is why we both adjusted each other and became a group."

Academic skills were not taught directly, and participant children learned with fun. For example, one volunteer (Volunteer 3) said the following on this issue:

"Children learned academic skills in indirect/pseudo-activities, they were not activities per se. I believe that summer programs should be like that. As we see in our education, it is embedded learning."

\subsubsection{Benefits for families}

A total of five parents experienced that they have been supported in different ways in the program. Four of them said that they felt more social support because of sharing experiences with other parents in the program. One of the most common benefits stated by five parents was having leisure time and doing something just for themselves while their children were in the program. One mother (Parent 7) said, for example, "We shared our experiences when we met in the garden. I will miss them because they contributed to my knowledge." Another mother (Parent 3) remarked, "I have no longer old friends... I have met mothers who have similar histories, concerns and expectations."

\subsubsection{Diversity of program content}

The last sub-theme emerged pertains to a group of various issues. Pairing a child with ASD and a volunteer as a sub-group was seen a powerful characteristic by three parents and four volunteers. While all sub-groups worked separately and individually in IEP sessions, they were also a part of the big group working collectively. One mother (Parent 
8) said, "Actually, children with ASD had everything they needed. They were in a large group and they were at the same time with their volunteer."

Support from professionals coming from different disciplines and the workshops conducted by these professionals who were considered experts working on ASD by both groups were evaluated as factors that further enriched the program.

Diversity of activities and content including sport, art, physical activities, small group activities, large group activities, outdoor activities and games were found attractive by six parents and six volunteers. One volunteer (Volunteer 4) stated the following:

"We did activities, physical activities, yoga, played games...we spent more time in the garden. They were all included in the summer program."

This diversity was highlighted by another volunteer (Volunteer 2):

"Neither we nor the families participated in the program with academic expectations. Social activity was dominant... We played games ... We met various professionals, they shared their experience with us... We went out into the garden, we played ball games and water games."

Parents particularly stated that they would otherwise have difficulty in reaching the entire services offered in the program. It was considered as a strong part by two parents including one mother and one grandmother. The grandmother said (Parent 2),

"As families, we are not able to take our children to many activities with different people in one day. One day you are invited to an activity with someone who is an expert on ceramic.... and the next day on music."

\section{Discussion}

This study explored the perspectives of parents and pre-service volunteer special education teachers regarding a summer program carried out for children with ASD. The findings were presented on the basis of three main themes including the need of summer program, suggestions for effective summer program, and benefits of summer program. The results provide some preliminary descriptive data regarding perspectives and attitudes of parents of children with ASD and pre-service special education teachers who volunteered at a summer half-day camp program as a pair of a child with ASD.

According to the findings, it is very clear that the opportunities in summer for children with ASD are limited and families need to be supported. The participants reported that restrictions in summer led to isolation and parents shared their concerns to access free services for their children. This result is supported by the study emphasizing that for most children, summer is synonymous with freedom and fun, but for those with 
ASD whose summer activities are often limited to their houses, they are exposed to isolation and distress (Siperstein et al., 2011).

In the current study, all sub- and large- group activities accompanied by volunteers had a positive effect on social and academic skills of participants with ASD. The most obvious improvement was seen in the social skills across the program, which was confirmed by both participant groups. This result is consistent with consideration of summer programs to represent an encouraging way to enhance social skills of children with ASD (Lopata et al., 2006; Lopata et al., 2008; Walker et al., 2010). The reported increase in social and academic skills can be discussed within several factors. The inclusion of volunteers with basic skills to work with children with ASD as selected mostly amongst the senior students in special education department may have a role in this improvement. Another possible explanation involves the construction features of the program like focusing large-group activities, out-door activities and getting services from experienced professionals in ASD.

It is suggested that summer may be used as a time to develop academic skills (Westervelt et al., 1998). Setting goals provide an opportunity to make the needs of each participant with ASD more personal and this guidance helps to design and implement the program (Boeder, 2012). The current program also focused on academic skills in IEP sessions and the goals were determined before the program. During the visit to families before the program, volunteers acquired more background information on each participant, such as current performance level on basic academic skills, preferred reinforcers or activities, which might have greater effect to achieve IEP goals. Additionally, the volunteers became more familiar with their paired child with ASD during the visit to the family and they probably chose more achievable academic goals. Despite the availability of very limited training for parents, they reported high satisfaction for a workshop that was held on how to deal with problem behaviours of their children. Why this three-hour psycho-educational session was found so highly satisfactory should be discussed within the framework of some cultural issues as well as social and financial means in Turkey. Turkey is a developing country where individuals with special needs and their families have been provided with education and social rights over last two decades. This satisfaction may also indicate that parents mostly do not have social support and they expect to receive training on how to approach their children's difficult behaviours, which has been previously identified by studies conducted with Turkish mothers (Değirmenci, 2019; Güleç-Aslan, 2017).

The findings of the present study clearly suggest that the success of volunteering program depends on several factors related to not only structure but also issues involving partners, families, ASD communities, and volunteers. The quality of structure can be achieved by satisfying participants' expectations better through well-constructed programs. These expectations include diversified content, grouping children with ASD according to the severity of ASD, more effective and frequent communication between families and volunteers. Wardell et al. (2000) stated that a well-structured program, 
continuous support and training are prerequisites to a satisfactory volunteer program. The current program has fulfilled all these prerequisites.

The high level of satisfaction reported by volunteers and parents seems to be related to the motivation of both groups. Parents demonstrated their motivation as an opportunity for the social rather than academic development of their children. This aim was achieved through structured art activities in small or large groups. Schleien et al. (1995) consider the inclusion of children with ASD in art-related activities to be an encouraging way to develop their skills. In addition, group format provides more natural opportunity for interaction (Solomon et al., 2004) and are also recommended for social skill intervention (Lopata et al., 2008).

It is thought that the development of social skills of children with ASD is closely related to skills of volunteers, given that they know how to struggle with problem behaviours, to provide reinforcers and to integrate activities in accordance with the goal. Previous studies indicate that volunteers in summer programs were commonly peers (Boyd et al., 2008), whereas in the current research pre-service teachers volunteered. The limited access to trained volunteers may reduce impact of volunteering programs. Moreover, training and supporting the volunteers require considerable amount of resources (Nieto et al., 2015). In the current study, pairing a child with ASD and a volunteer, a pre-service special education teacher, contributed positively to achievements of the program. As pointed previously, some volunteers had experiences in teaching and working with individuals with special needs and all of them took practice courses in special education institutions and universities during their undergraduate education. In addition, volunteers stated that participation in summer program has a positive impact on professional and personal development of them and this finding is consistent with previous studies (Moore \& Allen; 1996; Nieto et al., 2015).

Although the study contributes to the literature, there were a number of limitations. Though the volunteers were relatively better-informed compared to other summer program studies, professionals could have been included in the program such as an occupational therapist to observe and regulate participants' sensory profiles, a professional to engage all participants to inclusive physical activities to develop ageappropriate motor skills by individualizing instructions and a counsellor to manage challenging behaviours of children with ASD some of which resulted from adolescence. In a study that aimed to reduce core deficits and enhance social adjustment of children with ASD, social groups consisted of psychologist and a speech and language pathologist to consult about issues arising in the group (Solomon et al., 2004). In addition, despite the well-planned program, the fragmentation caused by the size of the school was particularly observed during large group activities. Future programs should opt for smaller units to conduct the program to prevent possible problems that could diminish the effectiveness and to control the environment.

Nonetheless, despite these limitations, the findings of this qualitative study represent a valuable contribution to the literature by clarifying the problems of families of children with ASD regarding long summer break, highlighting the importance of 
working in collaboration with different disciplines and the contribution of pre-service teachers who obtain a chance to practice with a group of children with ASD. Planning and conducting summer programs appears to be of remarkable importance for maintaining current level of functioning in children with ASD.

\section{About the Author}

Hatice Şengül Erdem, PhD, is an assistant professor in Special Education Department at İstanbul Medipol University, Turkey. Her research areas are autism spectrum disorders, siblings of children with ASD, and early intervention. Her Orcid is https://orcid.org/0000$\underline{0002-3970-7084}$

\section{References}

Bobzien, J. L., \& Judge, S. (2014). Characteristics of peer models at a summer camp for children with autism. Journal for Multicultural Education, 8(4), 237-248. https://doi.org/10.1108/JME-04-2014-0017

Boeder, W. V. (2012). Behavior analytic goal setting and tracking at a therapeutic summer camp: an approach for children with autism spectrum and other disorders [Master's thesis, University of Wisconsin-Milwaukee]. UWM Digital Commons, Theses and Dissertations. https://dc.uwm.edu/cgi/viewcontent.cgi?article $=1027 \&$ context $=$ etd

Boyd, C. M., Fraiman, J. L., Hawkins, K. A., Labin, J. M., Sutter, M. B., \& Wahl, M. R. (2008). Effects of the Star intervention program on interactions between campers with and without disabilities during inclusive summer day camp activities. Education and Training in Developmental Disabilities, 43(1), 92-101. http://www.jstor.com/stable/23879746

Brantlinger, E., Jimenez, R., Klingner, J., Pugach, M., \& Richardson, V. (2005). Qualitative studies in special education. Exceptional Children, 71(2), 195-207. https://doi.org/10.1177/001440290507100205

Brookman, L., Boettcher, M., Klein, E., Openden, D., Koegal, R. L., \& Koegal, L. K. (2003). Facilitating social interactions in a community summer camp setting for children with autism. Journal of Positive Behavior Interventions, 5(4), 249-252. https://doi.org/10.1177/10983007030050040801

Cooper, H., Nye, B., Charlton, K., \& Lindsay, J. (1996). The effects of summer vacation on achievement test scores: A narrative and meta-analytic review. Review of Educational Research, 66(3), 227-268. https://doi.org/10.3102/00346543066003227

Creswell, W. J. (2014). Educational research: planning, conducting, and evaluating quantitative and qualitative research. Pearson.

Cross, E. R. (2013). Regression among students with autism spectrum disorders: An examination of extended school year programming [Doctoral Dissertation, Temple University]. ProQuest Dissertations and Theses database. 
PERSPECTIVES OF VOLUNTEER PRE-SERVICE TEACHERS AND PARENTS

ON A SUMMER PROGRAM FOR CHILDREN WITH AUTISM SPECTRUM DISORDERS

https://search.proquest.com/openview/93636cc4276ad2fc89a860aab95c9ae7/1?pqorigsite $=$ gscholar $\& \mathrm{cbl}=18750 \&$ diss $=\mathrm{y}$

Degirmenci, G. Y. (2019). "Summer doesn't come with a single rose": A qualitative research of Turkish mothers' social support systems who have a child with ASD. Toplum ve Sosyal Hizmet, 30(2), 519-537. https://doi.org/10.33417/tsh.572216

Duncan, J. J. (2016). The impact of summer break from school on children with severe autism and their parents: An interdisciplinary study. [Doctoral dissertation, Laurentian University].

Semanticscholar. https://zone.biblio.laurentian.ca/bitstream/10219/2688/1/DuncanthesisDecember2 016.pdf

Golafshani, N. (2003). Understanding reliability and validity in qualitative research. The Qualitative Report, 8(4), 597-606. https://nsuworks.nova.edu/tar/vol8/iss4/6

Gülec-Aslan, Y. (2017). The life experiences of Turkish mothers who have children with an Autism Spectrum Disorder. Advances in Social Sciences Research Journal, 4(6) 149169. https://doi.org/10.14738/assri.46.2812

Hilton, C. L., Crouch, M. C., \& Israel, H. (2008). Out-of-school participation patterns in children with high-functioning autism spectrum disorders. The American Journal of Occupational Therapy, 62, 554-563. https://doi.org/10.5014/ajot.62.5.554

Kaboski, J. R., Diehl, J. J., Beriont, J., Crowell, C. R., Villano, M., Wier, K., \& Tang, K. (2014). Brief report: A pilot summer robotics camp to reduce social anxiety and improve social/vocational skills in adolescents with ASD. Journal of Autism and Developmental Disorders, 45(12), 1-8. https://doi.org/10.1007/s10803-014-2153-3

King G., Law M., King S., Rosenbaum R., Kertoy M. K., \& Young N. L. (2003). A conceptual model of the factors affecting the recreation and leisure participation of children with disabilities. Physical \& Occupational Therapy in Pediatrics, 23, 63-90. https://doi.org/10.1080/J006v23n01 05

Law, M., \& King, G. (2000). Participation! Every child's goal. Today's Kids in Motion, 1, 1012.

Leslie, E. (2018). How environmental education-based camps can create an inclusive opportunity to ensure children with autism have a positive and meaningful experience [Master's thesis, Hamline University]. Digitalcommons. https://digitalcommons.hamline.edu/hse $\mathrm{cp} / 246$

Lopata, C., Thomeer, M. L., Volker, M. A., \& Nida, R. E. (2006). Effectiveness of a cognitive-behavioral treatment on the social behaviors of children with Asperger disorder. Focus on Autism \& Other Developmental Disabilities, 21(4), 237-244. https://doi.org/10.1177/10883576060210040501

Lopata, C., Thomeer, M. L., Volker, M. A., Nida, R. E., \& Lee, G. K. (2008). Effectiveness of a manualized summer social treatment program for high functioning children with autism spectrum disorders. Journal of Autism \& Developmental Disorders, 38(5), 890-904. https://doi.org/10.1007/s10803-007-0460-7

Maich, K., Hall, C. L., Rhijn, T. M., \& Quinlan, L. (2015). Developing social skills of summer campers with autism spectrum disorder: A case study of camps on tracks 
PERSPECTIVES OF VOLUNTEER PRE-SERVICE TEACHERS AND PARENTS ON A SUMMER PROGRAM FOR CHILDREN WITH AUTISM SPECTRUM DISORDERS

implementation in an inclusive day-camp setting. Exceptionality Education International, 25 (2), 27-41. http://ir.lib.uwo.ca/eei/vol25/iss2/1

Menousek, P. E. (1984). An analysis of the factors affecting regression and recoupment of skills of special education students following summer vacation [Doctoral Dissertation, University of Nebraska]. ProQuest Dissertation Abstracts International. https://search.proquest.com/docview/303167560

Moore, C. W., \& Allen, J. P. (1996). The effects of volunteering on the young volunteer. The Journal of Primary Prevention, 17, 231-258. https://doi.org/10.1007/BF02248794

Nieto, C., Murillo, E., Belinchón, M., Giménez, A., Saldaña, D. Martínez, M., \& Frontera, M. (2015). Supporting people with Autism Spectrum Disorders in leisure time: Impact of an university volunteer program, and related factors. Anales de Psicología, 31(1), 145-154. http://dx.doi.org/10.6018/analesps.31.1.166591

Patton, M. Q. (1990). Qualitative evaluation and research methods. Sage.

Randel, A. B., Sorenson, C., Schenkelberg, M., Grefer, M. L., Flory, K., \& Beets, M. (2015). Camp PALS: An innovative summer camp program for youth with developmental disabilities. Emotional \& Behavioral Disorders, 57-64.

Rynders, J. E., Schleien, S. J., \& Mustonen, T. (1990). Integrating children with severe disabilities for intensive outdoor education: Focus on feasibility. Mental Retardation, 28, 7-14.

Schleien, S. J., Mustonen, T., \& Rynders, J. E. (1995). Participation of children with autism and nondisabled peers in a cooperatively structured community art program. Journal of Autism and Developmental Disorders, 25(4), 397-413. https://doi.org/10.1007/BF02179375.

Siperstein, G. N., Pociask, S., \& Barnes, K. (2011, September). Let's ALL Play: Helping to Make Inclusion in Summer Camps a Success. Acacamps. https://www.acacamps.org/resource-library/camping-magazine/lets-allplayhelping-make-inclusion-summer-camps-success.

Solish, A., Perry, A., \& Minnes, P. (2010). Participation of children with and without disabilities in social, recreational and leisure activities. Journal of Applied Research in Intellectual Disabilities, 23, 226-236. https://doi.org/10.1111/j.14683148.2009.00525.x

Solomon, M., Goodlin-Jones, B. L., \& Anders, T. F. (2004). A social adjustment enhancement intervention for high functioning Autism, Asperger's syndrome, and pervasive developmental disorder NOS. Journal of Autism and Developmental Disorders, 34(6), 649-668. https://doi.org/10.1007/s10803-004-5286-yh

Strauss, A. L., \& Corbin, J. M. (1998). Basics of qualitative research techniques and procedures for developing grounded theory (2nd ed.). Sage.

Quinn, C., Nowosielski, A., Kitchen, T., \& Belfiore, P. J. (2014). The role of program consistency in a summer therapeutic camp for students with autism spectrum disorder. Journal of Education and Learning, 3(3), 95-107. http://dx.doi.org/10.5539/jel.v3n3p95 
Walker, A. N., Barry, T. D., \& Bader, S. H. (2010). Therapist and parent ratings of changes in adaptive social skills following a summer treatment camp for children with autism spectrum disorders: A preliminary study. Child \& Youth Care Forum, 39(5), 305-322. https://doi.org/10.1007/s10566-010-9110-xh

Wardell, F., Lishman, J., \& Whalley, L. J. (2000). 'Who volunteers?' British Journal of Social Work, 9(2), 227-248. https://doi.org/10.1093/bjsw/30.2.227h

Westervelt, V. D., Johson, D. C., Westervelt, M. D., \& Murrill, S. (1998). Changes in selfconcept and academic skills during a multimodal summer camp program. Annals of Dyslexia, 48, 191-212. https://doi.org/10.1007/s11881-998-0009-2

Yıldırım, A., \& Şimşek, H. (2005). Sosyal bilimlerde nitel araştırma yöntemleri [Qualitative research methods in social sciences]. Seçkin. 
Creative Commons licensing terms

Authors will retain the copyright of their published articles agreeing that a Creative Commons Attribution 4.0 International License (CC BY 4.0) terms will be applied to their work. Under the terms of this license, no permission is required from the author(s) or publisher for members of the community to copy, distribute, transmit or adapt the article content, providing a proper, prominent and unambiguous attribution to the authors in a manner that makes clear that the materials are being reused under permission of a Creative Commons License. Views, opinions and conclusions expressed in this research article are views, opinions and conclusions of the author(s). Open Access Publishing Group and European Journal of Special Education Research shall not be responsible or answerable for any loss, damage or liability caused in relation to/arising out of conflict of interests, copyright violations and inappropriate or inaccurate use of any kind content related or integrated on the research work. All the published works are meeting the Open Access Publishing requirements and can be freely accessed, shared, modified, distributed and used in educational, commercial and non-commercial purposes under a Creative Commons Attribution 4.0 International License (CC BY 4.0). 